\title{
Ecological Approaches from Past to Present: Traditional Architecture of Cappadocia Region
}

\author{
Serife Ozata
}

\begin{abstract}
Cappadocia, which is popular with its natural scenic beauty, also has many important and special vernacular architectural features. In this study, architectural examples which were built in Cappadocia were analyzed in terms of energy saving, economic efficiency and compatibility with nature design in the areas which are similar to Cappadocia geologically and climatically. The necessity and advantages of an integration of today's technology and vernacular architecture for today's architecture can be explained by working on the solutions for material problems, natural ventilation, chimney design and natural lightning of the buildings of Cappadocia, which are rock-cut, rock-cut\& masonry and masonry.
\end{abstract}

Index Terms - Cappadocia, traditional materials, ventilation and chimney design, natural lighting.

\section{INTRODUCTION}

Due to the variety of materials and technical opportunities which are developed with the help of technology, architects leave traditional construction methods in today's architecture. Buildings which do not have traditional characteristics are designed instead of buildings which are designed by taking into account climatic conditions, conventional cultural features and traditional methods.

Cappadocia is a unique region which has rock-cut and masonry buildings. Because Bahceli Village has the general features of the traditional architecture of Cappadocia, it was selected as our study area. As a goal of this study, traditional and ecological approaches to natural ventilation, lighting and construction methods were determined for constituting sample solutions and providing data for today's and present's buildings.

Zhu et al. say that construction plays an important role in the influence of humans on nature and creating a construction which can get along with nature in a harmonious way has great theoretical and practical significance [1]. In that case, transferring and developing data of conventional buildings in the study area which are designed by taking into consideration the concept of respect to nature is very important for building design. Xu-Dong et al. explain this importance by saying that "Traditional buildings can give us edification about ecological architecture", [2].

We hope that the data of this study will be a useful sample for architects who want to design buildings which are harmonious with environment, have traditional and ecologic

Manuscript received May 15, 2014; revised July 24, 2014

S. O. is with the Yildiz Technical University, Faculty of Architecture, Istanbul, Turkey (e-mail: sozata@yildiz.edu.tr, ozataserife@gmail.com). solutions in the regions which have climatic and geographical characteristics similar to those of Cappadocia.

The scope of this study is limited to approaches of traditional and ecologic building in Bahceli Village. Analytic, qualitative and descriptive methods are used for explaining these approaches.

\section{CAPPADOCIA REgION AND TRADITIONAL ARCHITECTURE}

The Cappadocia region is located in Central Anatolia, Turkey. Defining the exact boundaries of Cappadocia is difficult due to its changing borderlines in history. According to most of the written documents, it is bordered by Taurus Mountains in the south, Kizilirmak River in the north, Kayseri province in the east and Tuzgölü basin in the west [3]. Boundaries of Cappadocia Region according to its morphological characteristics are limited by boundaries of

Nevsehir province and a valley of Kayseri province, Soganlı (Fig. 1) [8].

Winters are cold, rainy and snowy; summers are hot and dry. Continental climate is dominant in the region [9]. The rainiest months are March and December and the hottest and driest months are July and August. Dominant winds blow from north [10].

There are three main building types in Cappadocia. These are rock-cut, rock-cut \& masonry and masonry buildings. Rocky earth of the region has great effects on the vernacular architecture.

\section{A. Bahceli Village}

Bahceli is a village of Nevsehir province (Fig. 1). It was selected as a study area because buildings in that area have similar architectural, climatic and geographical characteristics to other buildings in the entire region. Seeing all building types of Cappadocia Region is possible in there.

The village is located in a valley. The bottom of the valley is in the east and the most ancient settlements are in that area (Fig. 2) because this part of the village is surrounded by rock slopes which are suitable for carving buildings.

\section{ECOLOGICAL APPROACHES OF VERNACULAR ARCHITECTURE}

All three different building types of the Cappadocia region exist in the village. Methods of the choice and use of materials which have been used in these types of buildings, natural ventilation, chimney solutions and natural lighting system are explained in this section.

\section{A. Types of Building}

There are three building types in Cappadocia that have 
been studied in the scope of this study. These are rock-cut, rock-cut \& masonry and masonry.
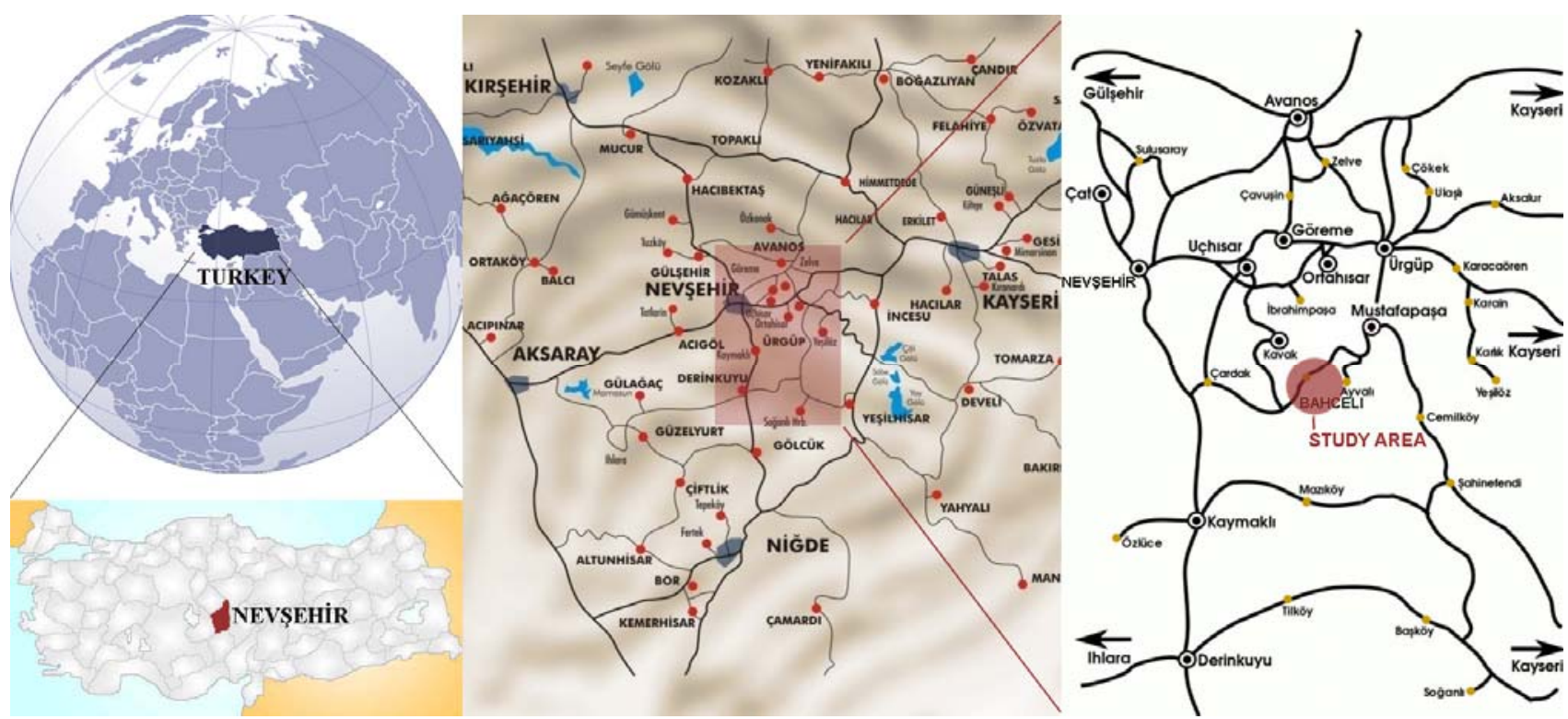

Fig. 1. The place of cappadocia region and study area [4]-[7].

- Rock-cut buildings: These kinds of buildings are constituted by carving massive rocks according to necessity of space. These buildings are also a type of earth-sheltered buildings. According to Xu-dong, traditional cave dwellings have become an important developing direction in architecture because of its energy-saving characteristics [2].

- Rock-cut \& masonry buildings: These buildings are named as rock-cut \& masonry because some of their parts consist of carved rocky earth and other parts are masonry. Cave dwelling parts are generally in the first floor and other parts are above the carved parts. These buildings have the characteristics of both types.

- Masonry buildings: These types of buildings have structures which are made of stone (special to this region) and bound together with mortar. All types have a special traditional construction process. They are shown in Fig. 3.

\section{B. Material Solutions}

Traditional materials are used in the construction of vernacular architecture because they are harmonious with environment and their transportation is easy. Using traditional materials is energy saving, too.

Geological characteristics of the region have great effects on the regions' architecture. The study area, Bahceli Village, is located in the Cappadocia Volcanic Province (CVP) (Fig. 4). As seen in Fig. 4, the village is in the volcaniclastic and cinder cone field (in Urgup Formation). Total thickness of the formation is more than $400 \mathrm{~m} \mathrm{[12].} \mathrm{Stratigraphic} \mathrm{of} \mathrm{the}$ ignimbrites (tuffs) in the area (Fig. 4) shows that there are more than 10 units, and they have different characteristics [3]. Details of the characteristics of ignimbrites are beyond this study but let us just note that soft tuffs are on the bottom layers and volcanogenic hard lava rocks are generally on the top layers in the stratigraphy of the region [13]. Rock type of the study area is generally tuff and there are small mountains

which have different ignimbrite layers around the village. This different ignimbrite layers were used as a material source for three different building types in the village.
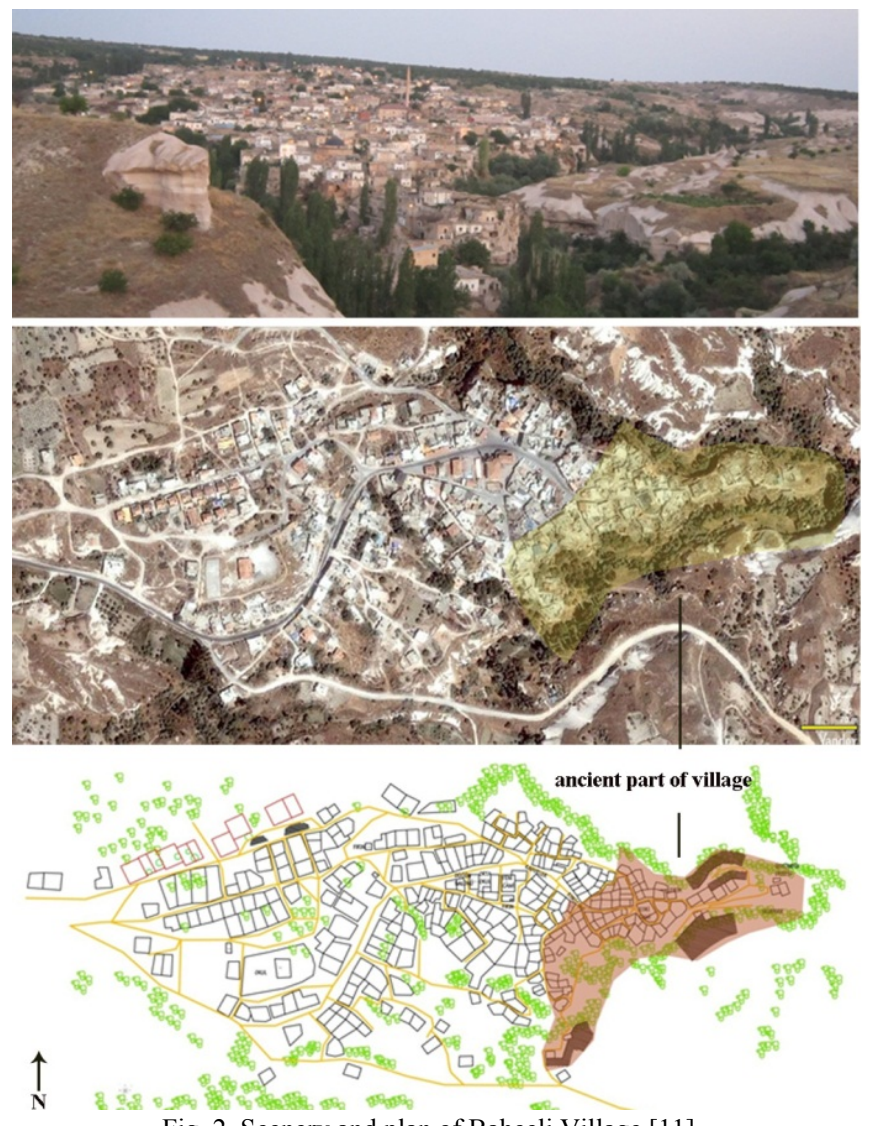

Fig. 2. Scenery and plan of Bahceli Village [11].

Rock-cut buildings are carved in the tuff layers and the whole structure is constituted in this rock layer. The most important characteristic of tuffs are their porous structure [14]. This characteristic is useful for providing heat and noise insulation but it also causes ambient air humidity when its' cavities are filled with water. This humidity problem was solved by thickening the section height of floor and ceiling of carved spaces.

The different characteristics of ignimbrite layers in the 
region have many advantages for masonry structures. Tuff stones which are carved near the village are used for walls. Basalt stones which are carved from the upper part of the mountains, $3-5 \mathrm{~km}$. far away from the village, are used to build water-repellent ceilings. The structure of these basalt stones is not very porous and they don't absorb water very much [14]. Humidity problem in the masonry buildings is solved by using the right material.

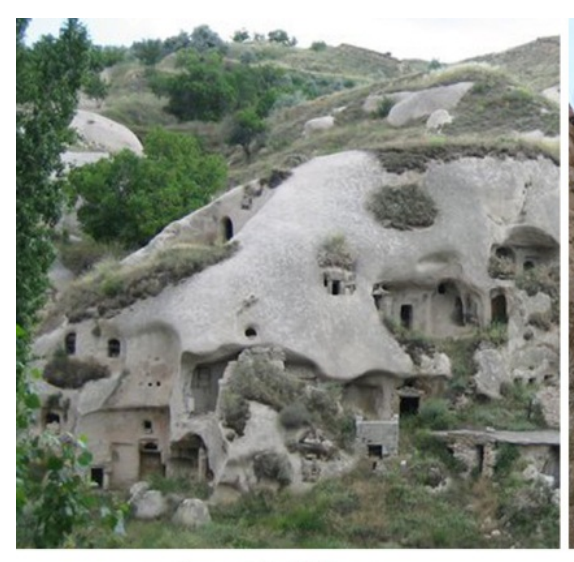

rock-cut buildings

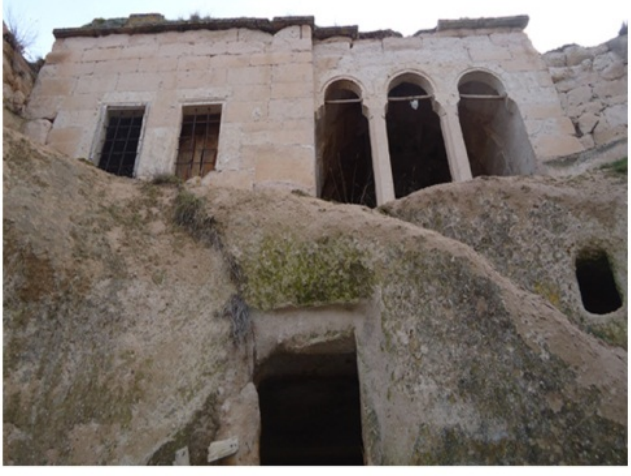

rock-cut\&masonry building

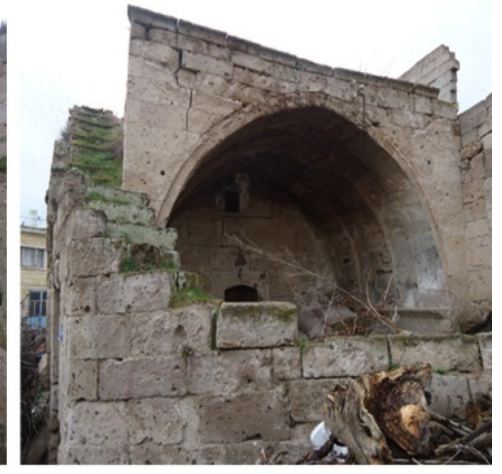

masonry building

Fig. 3. Building types.
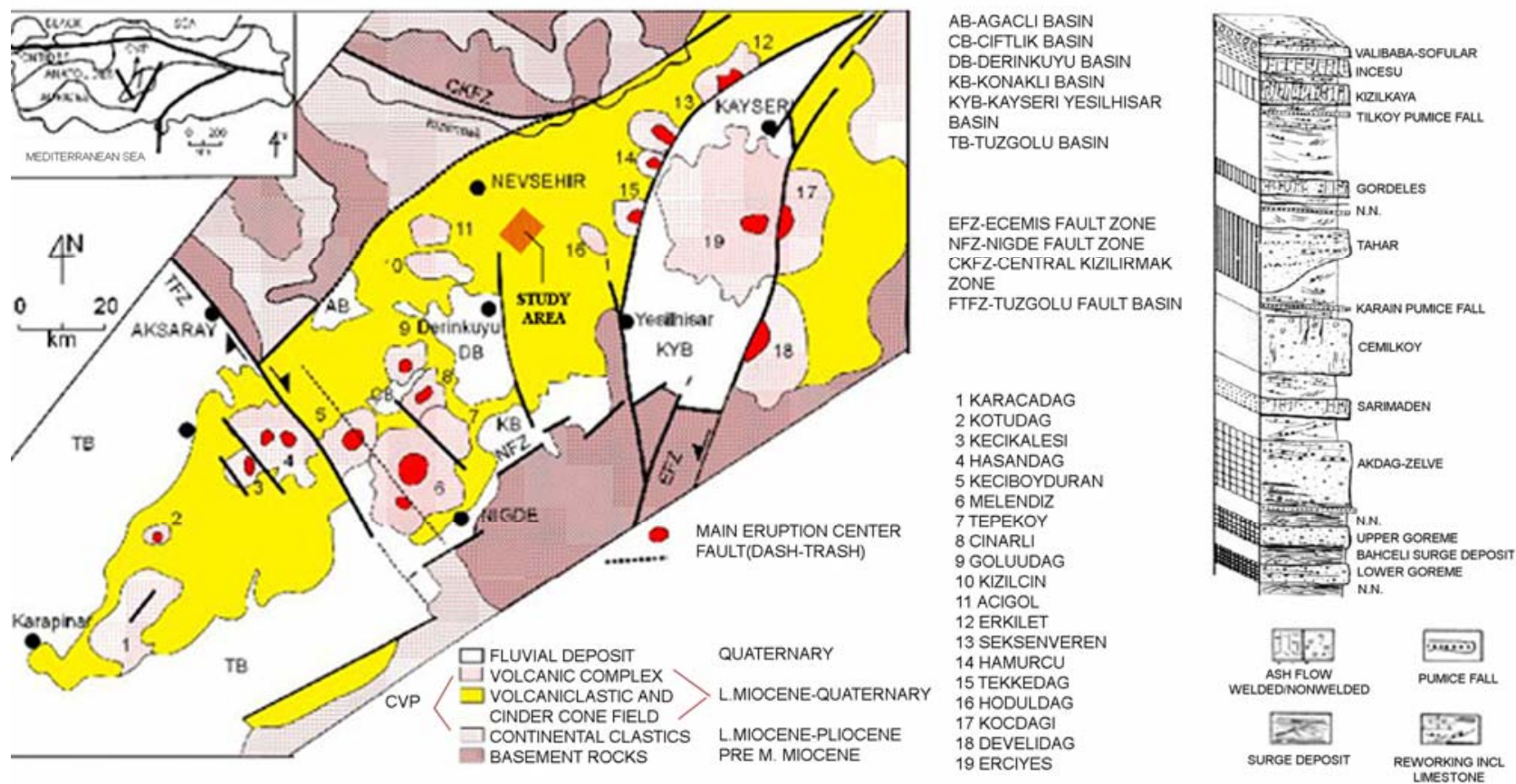

Fig. 4. Simplified geological map of the cappadocian volcanic province and stratigraphy of the ignimbrites in the area [3], [12].

Two types of floor are common in masonry structures: Stone and timber floors. Stone floors are designed like an arch. Pumice is used for filling the gaps between arches. This filling action decreases the loading of masonry and provides heat and noise insulation. Timber floors are flat. The beams of these floors are built with timbers of poplars which are grown near the stream of the village. Poplars are used for timber beams because they grow quickly in well-watered places and local people grow new ones continuously instead of cut ones. In addition, reed mats which are grown near the stream are used for heat and noise insulation like pumice fills. Details of floors are shown in Fig. 5.

Rock-cut \& masonry buildings are constructed with mixed methods of the two types of buildings. Upper part of the rock is made flat and this makes masonry structure on it possible. During this flatting process, rock is carved block by block and these blocks are used for masonry part of the structure. This method provides efficient use of material and workforce.

\section{Natural Ventilation and Chimney Solutions}

Ventilation system design is an important part of architecture because of its effects on people's health. Air pollution in a vernacular house of the village is generally caused by the smoke of clay oven which is used for warming or cooking.

Chimneys are an important part of ventilation just as windows are. Natural ventilation is possible with an efficient chimney. A well-known principle about fluids is used while chimneys are being designed. According to this principle," the narrowing section makes the speed of fluid higher.' So, the smoke leaves the space immediately. Moreover, there is a small hole which opens to an outer space and this hole provides oxygen for burning without smoking. Explained systems are shown in Fig. 6 and 7. 
The chimney of rock-cut buildings is constructed by carving the rock. As shown in Fig. 6, the section of chimney narrows. In addition, the traditional grain pots are used for constructing the chimney of masonry buildings. Using that kind of pots facilitates the process of chimney construction because they are found easily in the region and they are produced with regions' special clay. The pot and the chimney are shown in Fig. 7. The chimney of the rock-cut \& masonry buildings has similar features to the other two chimney types.
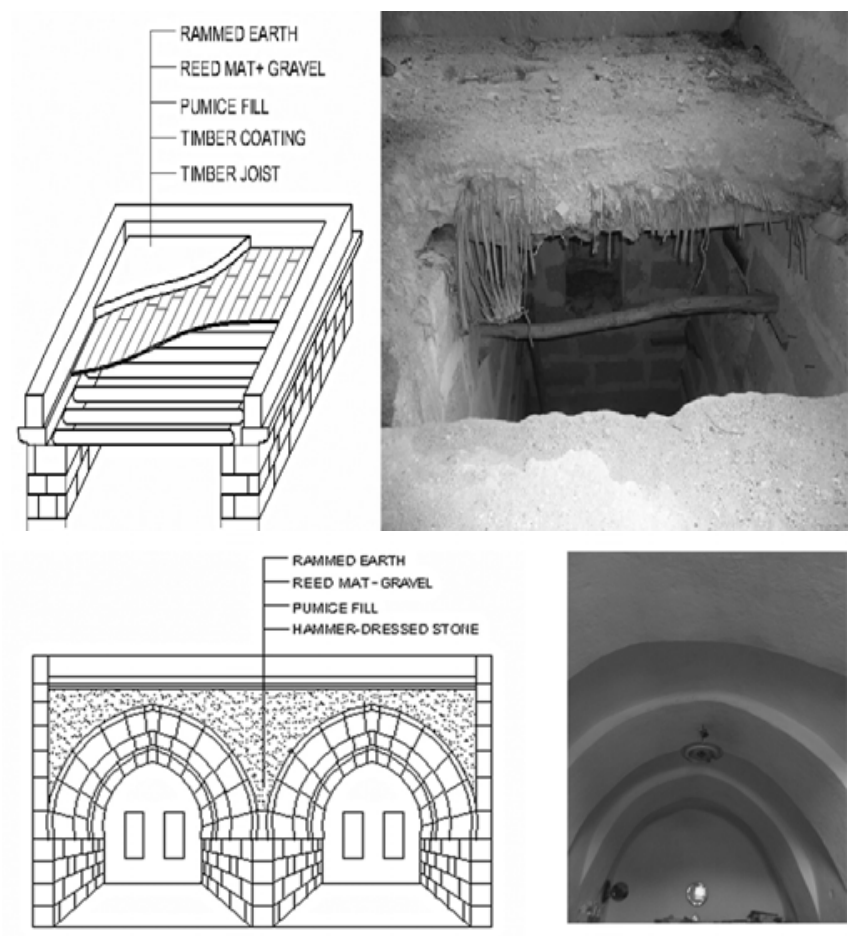

Fig. 5. Details of floor types.

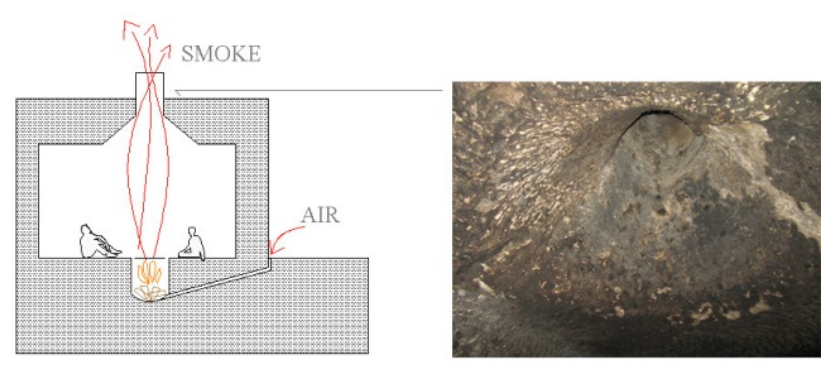

Fig. 6. Chimney detail of rock-cut building.

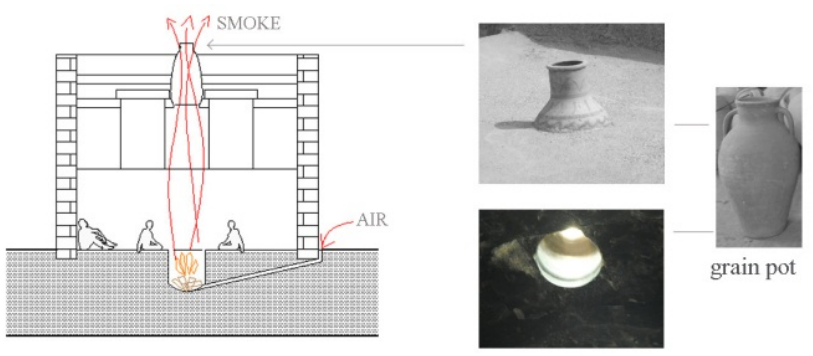

Fig. 7. Chimney detail of masonry building and used grain pot.

\section{Natural Ventilation and Chimney Solutions}

The amount of natural light of any kind of space is a very important aspect of building design. Windows are designed with an inclination from inside to outside, so that light is received effectively. This window design has two main aims. The former aim is providing more light for the inside part of a building; the latter is narrowing the external area of the window with minimal outer surface in order to prevent the entrance of cold air. These types of windows are generally common for rock-cut buildings.

Another common feature of buildings is rock sofas in front of the windows. The aims of designing sofas are making the area which is near to windows more lightened and generating a sitting area which exploits sunlight more effectively. Details of designed sofas and windows are shown in Fig. 8.

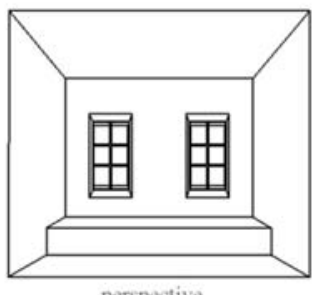

Fig. 8. Natural lighting solutions and rock sofa.
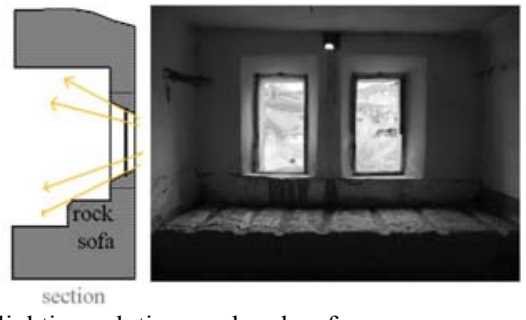

\section{CONCLUSION}

Providing an integration of today's technology and vernacular houses which are compatible with nature, have comfort requirements like heat and sound insulation and minimize the use of energy in regions like Cappadocia, which has cold climate in winters, hot and dry in summers, is very important for today's sustainable architecture. According to Esin et al., traditional design and construction process have constituted worthwhile examples of architecture by gathering local resources and workforces [15].

In the scope of this study, a village which has the general vernacular architectural features of Cappadocia Region, Bahceli Village, was chosen to work on and its' buildings' features about material types, natural ventilation, chimney design and lightning were explained. The outcomes of this research obtained from vernacular architecture are given below:

- Analyzing building types and features of the place where the building will be constructed is essential for constructing an ecological building in this place,

- Using local materials for the constructions without affecting the nature adversely is very important for protecting nature and for sustainable design,

- Design principles of natural ventilation system and chimney style should be decided according to the principle of "Remove the dirty air from the place quickly'. Some local equipment can be useful and has the potential of being used in a design as if it is a part of the construction. Therefore, all immediate environment of the building area should be analyzed in detail to see the opportunities

- While designing lighting, climatic characteristics and optimum quantity of sunlight should be considered in detail for designing effective windows.

Consequently, before designing a place in any area, if this area has a vernacular architecture, examples of this architecture should be researched. People have designed buildings compatible with environment for centuries but in recent centuries they have mostly ignored the environment 
while they design structures. Vernacular architectures have their own technology of their built time. Integrating them into today's architecture by finding out about them deeply is necessary for a sustainable architectural development.

\section{ACKNOWLEDGMENT}

I would like to thank H. Merve Tuncer, Neslihan Bardak, Sedef Sayin, Sagra Ozcayci and my family for their great support.

\section{REFERENCES}

[1] Y. Zhu, L. Xi, and L. Zhang, "Exploration on the ventilation design strategies of cave dwelling construction in northern part of Shaanxi province," Applied Mechanics and Materials, vol. 170-173, pp. 2574-2578, May 2012.

[2] Z. X. Dong and S. D. Ming, "From traditional cave to green design of modern earth-sheltered architecture: a case study of chongqing empirical study center of building energy conservation," Advanced Materials Research, vol. 368-373, pp. 3486-3489, October 2011.

[3] A. Ayhan, "Geological and morphological investigations of the underground cities of cappadocia using GIS," Master Thesis (unpublished), Middle East Technical University, Ankara, 2004, p.4,16

[4] Map of Cappadocia Region. [Online]. Available: http://www.villacolumba.com/kapadokya-gezi-rehberi/kapadokya-boe lge-haritasi/

[5] Turkey Map. [Online]. Available: http://www.turkcebilgi.com/harita/t\% $\quad$ C\%BCrkiye/dunya -uzerinde-turkiye-nerede

[6] Nevsehir Map.

[Online]. Available:http://www.turkiye-resimleri.com/r- nevsehir-54-nevsehir -haritasi-3510.htm

[7] Geographical Position of Nevsehir. [Online]. Available: http:/ www.nevsehir.gov.tr/ortak_icerik/nevsehir/contents/cografi_yapi.pdf

[8] D. U. Binan, "Güzelyurt örneğinde, kapadokya bölgesi yığma taş konut mimarisinin korunması için bir yöntem araştırması,', Doctorate Thesis, Y1ld1z Technical University, Istanbul, 1994, p. 5
[9] M. N. Sayın, "Fairy chimney development in cappadocian Ignımbrites (central anatolia, Turkey),' Doctorate Thesis, Middle East Technical University, Ankara, 2008, p. 2

[10] Nevsehir. [Online] Available: http://www.nevsehir.gov.tr/ortak_icerik/nevsehir/contents/ cografi_yapi. pdf

[11] Bahçeli+Köyü. [Online] Available: https://www.google.com/maps/place/Bahçeli+Köyü/@38.5478425,34. $8432902,15 \mathrm{z} /$ data $=! 4 \mathrm{~m} 2$ !3m1! $1 \mathrm{~s} 0 \times 152 \mathrm{a} 6 \mathrm{a} 1365 \mathrm{f} 1 \mathrm{e} 4 \mathrm{e} 9: 0 \times \mathrm{xba} 77373 \mathrm{a} 15$ $4 \mathrm{da} 44 \mathrm{c}$

[12] .O. Mutlu, "Geology and joint analysis of the derinkuyu and kaymakl1 underground cities of cappadocia, Turkey," Master Thesis, Middle East Technical University, Ankara, 2008, pp. 17-18

[13] M. Yıldırım and E. Gökasan, Mühendisler Için Jeoloji Bilgileri, Istanbul, 2013, ch. 3, p. 61

[14] H. Kaygısız, "Kayseri yöresindeki yapıtaşlarının fiziko-mekanik özelliklerinin belirlenmesi," Master Thesis, Cukurova University, Adana, 2010, p. 67

[15] T. Esin andİ. Yüksek, (April 2010). Geleneksel Yapilarda Sürdürülebilir Çatı Örnekleri. [Online] Available: https://drive.google.com/file/d/0B-0CJ3XhQ0E6TXhQRV1Sc0tMWX c/edit?pli=1

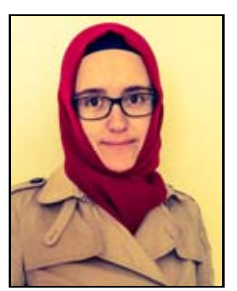

Serife Ozata was born in Nevsehir, Turkey in 1990 She received her B.S. degree as an architect from Y1ld1z Technical University in 2012. She has had undergraduate education at the Faculty of Architecture of Universidad de Alicante in Spain as an ERASMUS student for five months.

She worked as a research assistant in Kirsehir Ahi Evran University. Since 2013, working as a research assistant and studying on M.Sc. thesis at the Department of Architecture of Architecture Faculty of Yıldız Technical University in Istanbul, Turkey. Her research interests include rock-cut and masonry buildings, retrofitting-conserving-restoring historical buildings and sustainable architecture. 